\begin{tabular}{|c|c|}
\hline & $\begin{array}{l}\text { Journal of Communication Pedagogy } \\
\qquad 2021 \text {, Vol. 5, 31-39 }\end{array}$ \\
\hline $\begin{array}{l}\text { COMMUNICATION } \\
\text { PEDAGOGY }\end{array}$ & $\begin{array}{r}\odot \text { The Author(s) } 2021 \\
\text { Reprints and permissions: http://www.csca-net.oro }\end{array}$ \\
\hline & $\begin{array}{r}\text { DOI: } 10.31446 / J C P .2021 .2 .06 \\
\text { Central States Communication Association }\end{array}$ \\
\hline
\end{tabular}

\title{
Connection Over Correction: Engaging Students in Conversational Commitments for Effective Communication Across Difference and Difficulty
}

\author{
Jennifer Sandoval
}

Keywords: reflexive pedagogy, dialogue, identity, pedagogy of interiority, instructional communication

\begin{abstract}
In light of a national reckoning with racism in the U.S., many instructors are assessing their own pedagogical practices with regard to handling these topics in their classrooms. In developing my authentic teaching philosophy over the course of 18 years, I have adapted many practices I used in my prior career in dispute resolution. To clarify, I center classroom engagement around what Hart (2007) describes as "a pedagogy of interiority." Classroom engagement focuses on connection rather than correction as we help students develop their "authentic inner potentials" (p. 2). I regularly challenge myself to invite students to develop their authentic personal selves via contemplation and reflexivity. In doing so, we move from a teacher-centered focus to a student-centered one derived from a relational partnership with them. By focusing on connection rather than correction, we create an environment of curiosity, compassion, and intensive reflection where students come to know themselves and their strengths in ways that extend beyond the classroom. This essay highlights how students co-create conversational commitments coupled with a rapid debrief process that moves my students forward together toward shared mindfulness in thought and behavior.
\end{abstract}

In response to the myriad instances of racism so blatantly exposed throughout the U.S. in 2020, many instructors and departments are reviewing the way they address communication across difference in their classrooms and curricula. Although racism and its impact are not new, 2020 prompted an important reckoning-particularly for those who have not had to consider their own identities or those in their orbit due to embodied or other privileges. The context of the college classroom is a complex space embedded in larger structures and histories. Our own experiences and expectations are culture-bound 
and we make pedagogical choices that are often a reflection of that socialization into the field and into our own identities. Consciously or not, this influences the way students understand their roles, rights, and responsibilities in this slippery educational space. While this essay takes a more instrumental approach to classroom dialogue, it is essential to note that the embodied identity of an instructor, the composition of the group of students, and the institutional context matter deeply. Self-reflexivity is critical to the process of effectively engaging students in personal development and conscious conversation in ways that ultimately establish an inclusive and transformative classroom environment. In the spirit of Freire's "revolutionary educator" the goal of these approaches is to engage "... the quest for mutual humanization [with] efforts imbued with a profound trust in people and their creative power. To achieve this, [we] must be partners of the students in [our] relations with them" (1972, p. 75).

I am often asked to present to early career faculty or graduate students about how to manage conflict and tough topics in the classroom. Many instructors express anxiety about their ability to facilitate conversations around "difficult topics" (Brigley Thompson, 2020). Brigley Thompson (2020) suggests further that we can do so by creating and critiquing "safe spaces" for conversation. We can never truly promise a safe space, however, when it comes to communication about identity-especially for minoritized and marginalized students. The trauma many Black, Indigenous, and People of Color (BIPOC) in our classrooms have experienced at the hands of the U.S. education system cannot be underestimated (Harper \& Hurtado, 2007). While we cannot erase those experiences nor ensure the words and behavior of everyone around us will honor and respect difference, we can endeavor to construct safer spaces by engaging in considerable pre-conversation work and metacommunication. As Bahktin (1984 [1961-1962]) argues,

a single consciousness is a contradiction in terms. Consciousness is essentially multiple ... I am conscious of myself and become myself only when revealing myself for another, through another, and with the help of another ... the very being of [hu]man is the deepest communion. (p. 287)

Communication as dialogue, or conscious conversation, is the core of my pedagogy and approach to exchanges of self and understanding in the classroom.

Arguably, achieving conscious conversation through dialogue (Stewart, 1978) across difference is an ambitious goal. As my colleague, Keith Nainby, and I (Sandoval \& Nainby, 2017) argue, however, communication instructors can "make a place" that leads to transformation through relational dialogue. Doing so requires commitment to disrupting some of our taken-for-granted assumptions about what communication courses and classrooms look like, as well as who is afforded agency to drive engagement forward in those classrooms. As we (2017) explained, "efforts to raise consciousness or similarly focus on student empowerment in learning contexts are also contested because historically, notions of what counts as awareness, agency, and action are themselves the products of normative discourses" (p. 21). In other words, the nature of any classroom is power-laden. Consequently, dialectical tensions that exist across privilege and oppression, structure and agency, as well as embodied identity and positional roles must be addressed. I rely on Moore's (2014) Satisfaction Triangle that includes attending to issues, emotion, and process in order to work through these tensions as guiding forces that help create and maintain an inclusive classroom culture and climate.

While some instructors may believe classroom culture and climate only matter when teaching courses that contain "controversial" content (e.g., race, gender, sexuality), I argue that inclusive pedagogies in any classroom can foster a sense of belonging and opportunity to be heard, as well as to engage critically 
in learning. It is difficult to avoid centering ourselves in reflections about the practices of teaching. For these reasons, my philosophy is to approach the classroom as a shared learning space where we honor relational partnerships from a place of authenticity, compassion, and connection. The foundation of this approach is centered in bell hooks' "engaged pedagogy as a practice of freedom" .. " To teach in a manner that respects and cares for the souls of our students is essential if we are to provide the necessary conditions where learning can most deeply and intimately begin” (1994, p. 13).

To achieve these goals, I had to let go of my unrealistic perception that teachers must know all the answers and focus on correcting student mistakes and misperceptions. I have not escaped those cognitive habits, but they are overshadowed by my desire to connect. In essence, in order to construct an environment of curiosity, compassion, and intensive reflection, we must establish opportunities for our students to co-construct the environment in dialogic relationship.

Moreover, Hart (2007) argues that beyond cognitive learning goals-we are obligated to help students develop "their authentic inner potentials" by enacting a "pedagogy of interiority" (p. 2). I agree wholeheartedly, and we can only do so effectively when we have taken stock of our own authentic inner selves. Reflexive teaching practice involves more than merely taking a few notes about what did or did not work on a given day, week, month, or semester. We must also invite opportunities for our philosophy to evolve over time based on reflexive teaching as we co-construct meaning with our students (Freire, 1972; hooks, 1994). My own reflexive teaching over time has revealed, for example, that the experiences and expectations of students have held remarkably steady over time; however, their understanding of what it looks like to communicate effectively across difference has transformed.

To create an environment that fosters deep and challenging dialogue, I spend considerable time sharing personal goals and identifying expectations based on what they read in the syllabus as related to their previous experiences. Specifically, I break the class into small groups to discuss the following questions (see Table 1).

\section{TABLE 1}

\section{Questions for Co-Construction of Class Climate and Culture}

\begin{tabular}{|l|l|}
\hline $\begin{array}{l}\text { What are you most concerned about/nervous about after } \\
\text { listening to the introduction for this course? }\end{array}$ & $\begin{array}{l}\text { Identifying fears about content or engagement opens } \\
\text { up important self-reflection spaces and a shared under- } \\
\text { standing of what is at stake }\end{array}$ \\
\hline $\begin{array}{l}\text { What does it look like to discuss things we care about, } \\
\text { but may disagree about effectively and respectfully? }\end{array}$ & $\begin{array}{l}\text { It is often easy to identify things like "respect" as needs } \\
\text { for effective communication across difference, but } \\
\text { descripting how we experience respect is key }\end{array}$ \\
\hline $\begin{array}{l}\text { What are the things you need from each other in order to } \\
\text { engage in conscious conversations effectively? }\end{array}$ & $\begin{array}{l}\text { Thinking through what will contribute to an open and } \\
\text { safer climate is essential to building trust amongst peers }\end{array}$ \\
\hline $\begin{array}{l}\text { What are you willing to commit to as a member of this } \\
\text { class? }\end{array}$ & $\begin{array}{l}\text { Students/participants should reflect on the work they } \\
\text { will have to do to be a part of conscious dialogue }\end{array}$ \\
\hline $\begin{array}{l}\text { What do you need from Dr. S in order to engage in con- } \\
\text { scious conversations effectively? }\end{array}$ & $\begin{array}{l}\text { Positioning yourself, the instructor, as a partner in com- } \\
\text { mitment to effective dialogue sets the tone for all efforts }\end{array}$ \\
\hline $\begin{array}{l}\text { What has contributed to positive classroom environ- } \\
\text { ments and educational experiences for you? }\end{array}$ & $\begin{array}{l}\text { Past experiences influence what we bring into each new } \\
\text { space; however, we don't often remember the positive } \\
\text { environments-thinking through what we created that } \\
\text { can help determine what is needed }\end{array}$ \\
\hline $\begin{array}{l}\text { What has contributed to negative classroom environ- } \\
\text { ments and educational experiences for you? }\end{array}$ & $\begin{array}{l}\text { Negative past experiences may be easier to retrieve from } \\
\text { memory and they also provide essential information } \\
\text { about what will limit creation of safer spaces }\end{array}$
\end{tabular}


Contemplative pedagogy also provides a valuable framework for reflective practices where students can use their own lived experience to deepen their learning (Barbezat \& Bush, 2014). I also often ask students to reflect on what has contributed to positive educational experiences and spaces where they felt they could bring their authentic selves into the conversation. Conversely, I ask them to reflect on negative experiences and barriers that have prevented their fullest participation. These questions lead to valuable conversations about the characteristics of safer conversational spaces. Students often bring up experiences that have led them to participate less due to fears about being shamed by peers or professors, lack of knowledge about a topic, or the concern that their answer will reflect on their entire identity community (Steele \& Aronson, 1995). When asked, a majority of students report that they have never talked about how to engage in classroom discussion beyond information regarding how "participation" is measured for their grade. This is particularly concerning in the field of communication. I look at our classrooms as an opportunity to model and engage in group reflection about better practices and effective communication in complex contexts. This does take a small investment of time early on in a term, but a proactive approach has the potential to prevent problems later on as well as set an important tone for how to move through any challenges that emerge.

Student groups most frequently report feeling nervous about getting into arguments in class, being accepted, offending others, confrontation, and negative repercussions for their opinions. When asked how to approach class in ways that will ensure they do not experience these negative results, the overwhelming response is "respect." Students struggle to respond, however, when pressed to describe what respect in class discussions looks like. They do offer some specific actionable behaviors in the form of dos and don'ts:

Do listen attentively and actively.

Do make eye contact when speaking and listening.

Don't talk over one another.

Don't interrupt.

This list shows the ways many students have been socialized in "appropriate" classroom and conversational behavior. It is important to note these ideas are culturally bound and often problematic when applied to a diverse student group.

Students also bring up more ambiguous goals such as showing kindness, being sensitive, being supportive, being open-minded, and even being patient. It is important to reflect on the ways in which normative discourses have influenced students' expectations and fears as well. Most colleges and universities operate in similar ways in the U.S. and the "standards" for behavior are entrenched in White supremacist, patriarchal ideology. Students and instructors alike can have difficulty moving beyond the limits of our imagination when defining what transformative dialogue might look like.

After almost 2 decades of facilitating conversations about identity, discrimination, and injustice in both educational and professional settings, I rely on a few conversational commitments of my own that are intended to summarize some of the most effective approaches to engaging across difference through observing these conversations and feedback from students and participants (see Table 2). 


\begin{tabular}{|l|l|}
\hline \multicolumn{2}{|l|}{$\begin{array}{l}\text { TABLE } 2 \\
\text { Conversational Commitments }\end{array}$} \\
\hline Commitment & Description \\
\hline Be present & $\begin{array}{l}\text { Acknowledging the many people, thoughts, and stressors that are competing } \\
\text { for our attention and re-setting attention }\end{array}$ \\
\hline Speak your truth & Willingness to share lived experiences contributes to an open exchange \\
\hline Listen to understand & $\begin{array}{l}\text { Mindful listening means attending to what is being shared rather than focusing } \\
\text { on our own response }\end{array}$ \\
\hline Lean into discomfort & $\begin{array}{l}\text { Identify the difference between discomfort and harm and prepare students for } \\
\text { managing discomfort }\end{array}$ \\
\hline Expect and accept lack of closure & $\begin{array}{l}\text { Managed expectations about the outcomes of conscious dialogue around } \\
\text { experience and across difference }\end{array}$ \\
\hline Assume good intentions & $\begin{array}{l}\text { Enter conversation with the perspective that no one showed up today to hurt } \\
\text { you on purpose. Questions and comments likely come from a good place even } \\
\text { if they do not land well. }\end{array}$ \\
\hline Take responsibility for mistakes & $\begin{array}{l}\text { Intentions matter, but impact matters more; it is important to set an expec- } \\
\text { tation that when we make a mistake or cause harm we acknowledge it and } \\
\text { apologize }\end{array}$ \\
\hline Stories stay, lessons leave & $\begin{array}{l}\text { In conscious dialogue participants may share personal stories about their own } \\
\text { identities and experiences; members of the class should commit to honoring } \\
\text { those stories and keeping them confidential, but be able to share what they } \\
\text { learned from the narratives given }\end{array}$ \\
\hline
\end{tabular}

1. We agree to commit ourselves to being as present as possible. In my classes, we spend time acknowledging all the things that are competing for our attention but commit to at least putting in some effort to re-set and re-center when we arrive in our shared space.

2. We agree to speak our own truth while - at the same time-understanding that our individual truths may not be the same as those of other participants.

3. We agree to strive for honesty and the courage to share. We talk about mindful listening and the importance of listening to understand rather than listening to respond.

4. We agree to lean into discomfort. As such, we will be required to unpack the difference between discomfort and harm. While many of us may not have been socialized into spaces where we talk openly about things related to identity, it is often due to privilege that some are not required to confront topics of identity and discrimination daily.

5. We agree to both expect and accept a lack of closure. In other words, we acknowledge that we will not solve systemic racism or other structural problems in a matter of weeks. However, we can open new spaces for deeper understanding across difference. Being transparent about the challenge of conversations that may not lead to solutions but rather only to next steps is important when defining the goals of a dialogic approach. 
I have found these steps to foster a classroom climate and culture that are conducive to productive dialogic interactions. That said, there will be times when a conversation goes awry despite our attempts to prevent it from doing so. The way we address these situations is critical to getting back on track. Ignoring problematic statements, trying to simply move on, or shutting down dialogue completely are largely ineffective responses (Myers \& Rocca, 2001). However, we must acknowledge our own limitations, even temporary ones, to responding in the moment. When a class discussion has escalated to a point that it may harm students or instructor, I propose steps I have found useful to avoid destruction of the classroom climate (see Table 3).

\begin{tabular}{|l|l|}
\hline $\begin{array}{l}\text { TABLE } 3 \\
\text { Responses to Escalated Conversations }\end{array}$ & Note \\
\hline Response & $\begin{array}{l}\text { Never ignore a problematic statement or an escalation -that will } \\
\text { contribute to alienation of the students the comments harm }\end{array}$ \\
\hline Acknowledge the escalation & $\begin{array}{l}\text { Remind participants of their co-constructed commitments to engag- } \\
\text { ing ethically and with care; make sure the commitments are always } \\
\text { available for participants }\end{array}$ \\
\hline Re-visit salient conversational commitment & $\begin{array}{l}\text { Often it is valuable to de-escalate by ending the conversation at the } \\
\text { moment, but committing to revisiting the topic at the next meeting }\end{array}$ \\
\hline Take a break & $\begin{array}{l}\text { When you return create space to discuss why the conversation } \\
\text { escalated and what you can do to either prevent future problems or } \\
\text { respond more immediately to those same issues }\end{array}$ \\
\hline Debrief the escalation &
\end{tabular}

I should note here that it is critical to avoid weaponizing norms and expectations that reflect White supremacist and patriarchal structures. As hooks explains

If the effort to respect and honor the social reality and experiences of groups in this society who are nonwhite is to be reflected in pedagogical process then as teachers-on all levels ... we must acknowledge that our styles of teaching may need to change. (1994, p. 35)

Most of us have been socialized into a specific way of teaching that Freire (1972) called the "banking" approach to education. In this model instructors deposit information into students in an uncomplicated process that doesn't allow for human nuance. It is essential to recognize and validate a wide range of emotional expression when honoring difference (Biddle \& Hufnagel, 2019). The point of re-direction is to avoid harm and expand the ability of participants and students to engage across difference, not to engage in tone policing. Ira Shor (Shor \& Freire, 1987) provides a compelling example of broadening not only our ways of knowing, but also liberatory discourse. In describing his experience teaching after graduate school and attempting to create a "linguistic meeting ground" with his students, he explains,

What mattered, I think, was my refusal to install the language of the professor as the only valuable idiom in the classroom. My language counted, but so did theirs. My language changed, and so did theirs. This democracy of expression established a mutual atmosphere which encouraged the students to talk openly, not fearing ridicule or punishment. (p. 23) 
By ignoring harmful statements or escalation instructors can alienate students who are the targets of the ignorance or bigotry. The power imbalances in a classroom are real and we have to acknowledge those in our own participation. Reminding everyone of the commitments that were made to engage in ways that honor full personhood and dignity of all is valuable, but so is taking a break from the conversation while committing to re-opening engagement at a later date. Also critical is to openly discuss what went wrong and how to improve during the debriefing process, which serves as the important first step before restoring the climate and culture.

Finally, I realize the temptation to focus on content coverage and approaching the students in ways that lead to positive end-of-semester teacher/course evaluations. I also acknowledge that course content and student perceptions matter, but the process of dialogue and creating safer spaces for emotional expression are equally if not more critical as we teach students to live and work effectively in the world today. A number of studies have claimed significant deterioration in content retention the further students get away from the lecture, also known as the "forgetting curve" (Allen et al., 2011; Richards \& Frankland, 2017). While others point to a decrease in attention span for today's generation of college attendees (Bradbury, 2016). This has led to increased attention to practices of metacognition, active learning, contemplation, and other active practices outside memorization (Ambrose et al., 2010; Barbezat \& Bush, 2014; Fiorella \& Mayer, 2015). Thus, I challenge instructors at all levels to consider a superordinate goal of authentic personal development. By engaging students in the actual practices of effective communication across difference and difficulty, these can become measurable outcomes as well. For example, at the end of each of my class sessions, I do a rapid debrief (Supiano, 2019) to identify what worked well in our conversation that day and what we can adjust to do better next time (see Table 4).

\begin{tabular}{|c|c|}
\hline \multicolumn{2}{|l|}{$\begin{array}{l}\text { TABLE } 4 \\
\text { Rapid Debrief }\end{array}$} \\
\hline Question & \\
\hline What did we do today? & One or two students offer a quick summary of class activity and content \\
\hline What worked well today? & $\begin{array}{l}\text { Students list whatever approach or information was particularly effective or } \\
\text { meaningful }\end{array}$ \\
\hline What needs improvement? & $\begin{array}{l}\text { Together we identify any challenging moments or things that did not work } \\
\text { particularly well }\end{array}$ \\
\hline What's next? & I provide a brief summary of what is coming up in class and the next discussion \\
\hline What's giving you life this week? & $\begin{array}{l}\text { This is an opportunity for students to share high points of their week or any- } \\
\text { thing they are truly enjoying (e.g., music, a television show, a relationship) in } \\
\text { order to end on a fun and positive note }\end{array}$ \\
\hline
\end{tabular}

I find this immediate feedback technique to be vital in making micro-adjustments across the term rather than waiting for mid-term or end of the semester evaluations. Any adjustments I make are addressed transparently and if I am unable to fully respond to something identified as a problem we discuss why and how. Importantly, there are options to provide anonymous feedback online.

In closing, reflexive pedagogy invites students to participate in their education in a deeply meaningful way as it affords opportunities to move beyond basic content competency and toward mindfulness in thought and behavior. We can achieve this by making metacommunication and conversational agreements a 
center of practice and by focusing on connection rather than correction. We should strive to achieve this because it fosters lifelong skills regarding how to communicate effectively across difference and difficulty all people need to effectively co-construct reality of the complex world we inhabit together.

\section{References}

Allen, D. E., Donham, R. S., and Bernhardt, S. (2011). Problem based learning. New Directions for Teaching and Learning, 128, 21-29. https://doi.org/10.1002/tl.465

Ambrose, S. A., Bridges, M. W., DiPietro, M., Lovett, M. C., \& Norman, M. K. (2010). How learning works: 7 research-based principles for smart teaching. Jossey-Bass.

Bakhtin, Mikhail M. (1984 [1961-1962]). Toward a reworking of the Dostoevsky book. In Caryl Emerson (Ed.), Problems of Dostoevsky's poetics [Problemy tvorchestva Dostoevskogo], 283-302. University of Minnesota Press.

Barbezat, D. P., \& Bush, M. (2014). Contemplative practices in higher education: Powerful methods to transform teaching and learning. Jossey-Bass.

Biddle, C., \& Hufnagel, E. (2019). Navigating the "Danger Zone": Tone policing and the bounding of civility in the practice of student voice. American Journal of Education, 125(4), 487-520. https://doi. org/10.1086/704097

Bradbury, N. A. (2016). Attention span during lectures: 8 seconds, 10 minutes, or more? Advances in Physiology Education, 40(4), 509-513. https://doi.org/10.1152/advan.00109.2016

Brigley Thompson, Z. (2020). From safe spaces to precarious moments: Teaching sexuality and violence in the American higher education classroom. Gender \& Education, 32(3), 395-411. https://doi.org/1 0.1080/09540253.2018.1458077

Fiorella, L., \& Mayer, R. E. (2015). Learning as a generative activity: Eight learning strategies that promote understanding. Cambridge UP.

Freire, P. (1972). Pedagogy of the oppressed. Herder and Herder.

Harper, S. R., \& Hurtado, S. (2007). Nine themes in campus racial climates and implications for institutional transformation. New Directions for Student Services, 2007(120), 7-24. https://doi.org/10.1002/ ss. 254

Hart. T. (2007). Reciprocal revelation: Toward a pedagogy of interiority. Journal of Cognitive Affective Learning, 3(2), 1-10.

hooks, b. (1994). Teaching to transgress: Education as the practice of freedom. Routledge.

Moore, C. W. (2014). The mediation process: Practical strategies for resolving conflict (4th ed.). Jossey Bass.

Myers, S. A., \& Rocca, K. A. (2001). Perceived instructor argumentativeness and verbal aggressiveness in the college classroom: Effects on student perceptions of climate, apprehension, and state motivation. Western Journal of Communication, 65(2), 113-137. https://doi.org/10.1080/10570310109374696

Richards, B.A. \& Frankland, P.W. (2017). The persistence and transience of memory. Neuron, 94 (6), 1071-1084. https://doi.org/10.1016/j.neuron.2017.04.037

Sandoval, J. A., \& Nainby, K. (2017). Critical intercultural communication and critical communication pedagogy. In A. Atay \& S. Toyosaki (Eds.), Theorizing critical intercultural communication pedagogy. Lexington Press.

Shor, I. \& Freire, P. (1987). A pedagogy for liberation: Dialogues on transforming education. Bergin \& Garvey. 
Steele, C., \& Aronson, J. (1995). Stereotype threat and the intellectual test performance of African Americans. Journal of Personality and Social Psychology 69(5), 797-811. https://doi.org/10.1037/00223514.69.5.797

Stewart, J. (1978). Foundations of dialogic communication. The Quarterly Journal of Speech, 64, 183-201. Supiano, B. (2019, July 25). This professor ends class with a 'hotwash', a technique used by first responders. The Chronicle of Higher Education. https://www.chronicle.com/newsletter/teaching/2019-07-25 